\title{
Effects in Blended Classes That Utilize Clickers to Deepen Understanding of Information Technology
}

\author{
Isao Miyaji \\ Faculty of Informatics, Okayama University of Science, Japan
}

\begin{abstract}
In a blended lecture centering on exercises the students were asked to solve problems on paper, provided with explanatory materials, further explanations made using slides, and then asked to reply the degree of their understanding using clickers. They were also asked to reply answers of some problems using the clickers, and to reply with clickers when attendance was checked at the beginning of class. Questionnaire surveys were then carried out both before and after the class to identify how much the degree of recognition and attitude of the students had changed in the classes that utilized the clickers. Overall degree of term recognition was improved, and the overall amount of knowledge increased. Overall attitude related to abilities improved. It was achieved through various activities to deepen understanding of information technology.
\end{abstract}

\section{Introduction}

The clicker system, which allows for questions and answers as well as tabulations (graphs, etc.) during classes, has started being used in the fields of education recently. A clicker is a tool that can be used to summarize opinions and thus "addresses bidirectional communication in real time." It has moved into the spotlight as a tool that can be used to collect the opinions of the participants and instantly display the results at seminars or lectures at educational institutes or corporations [8].

A case of putting into practice active learning at an educational institute utilizing clickers as the class response system has already been reported upon [15]. According to Suzuki et al. [16], an improved memory retention rate, real-time feedback with regard to their degree of understanding, maintained concentration, increased attendance and so forth have been reported as some of the effects of using clickers.

Furthermore, an effective education program that uses an information system that was developed to integrate the response analyzer with lecture images has been proposed as a tool which is similar to clickers [11]. Its practical application has led to a report that the transmission of feedback from clickers does not interfere with the learning process and that the on-demand event reproduction system helps improve the class.

Sakai set up a class using Power Feedback NOTE, a system that synchronizes the clickers with video images, and reported that interest in the class, the degree of active participation, and concentration all improved [14].

The Central Education Council in Japan recommended that the blended learning is investigated after information and communication technology is introduced aggressively in line with the objectives of educational research [3]. It is possible to support many and various student learning styles and to deepen understanding by using more than one media [1], [2]. The use of e-learning, which cooperates with and expands the class, in the classroom is a useful means to improve the traditional class [9][10].

In this paper, college level education and the nurturing of problem-solving abilities via the incorporation of manufacturing and evaluation activities are involved [8]. It has already been reported that classes combining lectures, e-learning, small tests, lecture organization notes and so forth proved effective [6]. A report was also made that the effect could be further improved by increasing interactions with the instructor by incorporating questionnaire surveys on their degree of understanding [7].

As revealed above the utilization of clickers has been shown to improve the degree of participation as well as concentration in class. Therefore a blended class utilizing clickers in an exercise was developed for a subject of University A. Clickers were first used to check attendance. After revealing distribution explanatory slides were used to explain each problem and the students then requested to use the clickers to provide their degree of understanding. A questionnaire survey revealed a similar effect to that of previous studies [16] concerning the utilization of clickers in the class. In this paper questionnaire surveys were utilized both before and after the class in order to identify how much the degree of recognition and attitude of the students changed when clickers were used. The purpose of this paper is to reveal the change of their degree by utilizing clickers. The results of the analysis are reported herein. 


\section{Details and planning of the lectures}

\subsection{Planning of the lecture}

The subject class involved exercises on the subject of information at University A, and the morning problems of Fundamental Information Technology Engineer Examination (FE) [4] as the theme. As shown in Table 1 the classes took place as 15 ninety-minute sessions. Table 1 lists the media utilized in each class and e-learning. The total number of students was 43 .

The students were first asked to solve the actual morning problems of the FE. Texts describing the problems were distributed and slides displaying the distribution and percentage of correct answers for each problem were shown, and an explanation was provided based on the distributed texts via explanatory slides. The students were then asked to reveal their degree of understanding using clickers. The class therefore took place while their degree of understanding was verified in this way. The distributed texts comprised of the problems, answers, description of terms, how to solve the problems, and an explanation on each choice. The related terms and so forth were also described as much as possible. The explanations required about 1 to 2 pages per problem.
With the calculation problems exercises were provided on problems with different values after the explanation. The students were also asked to provide answers for approximately 10 problems using clickers. They were asked to write any questions on question forms and submit them at the end of the class. Answers to the questions were then provided at the beginning of the next class.

The purpose of the lecture was to deepen their understanding of information technology by solving the actual morning problems from the FE, providing explanations, and completing the exercises. The purpose of this was to enable the students to answer $60 \%$ or more of the morning problems of the $\mathrm{FE}$ correctly and thus pass the examination. It was also to improve their ability to solve various problems, something that is typically needed in actual society, through activities that deepen their knowledge of information technology.

\subsection{Contents of e-learning}

To intensify the effect of this lecture, e-learning functions were added as follows: (1) learning with 511 lecture slides; (2) learning with the 110 morning problems of FE; (3) learning with downloadable documents and one template; (4) submitting and uploading the exercise as report; (5) uploading

Table 1. Details and planning of the classes

\begin{tabular}{|c|c|c|c|c|c|c|c|c|c|c|c|c|}
\hline \multirow[b]{2}{*}{$\begin{array}{l}\text { We } \\
\text { ek }\end{array}$} & \multirow[b]{2}{*}{ Lecture contents } & \multicolumn{11}{|c|}{ Lecture } \\
\hline & & \begin{tabular}{|c}
$\begin{array}{c}\text { Lecture plan } \\
\text { manual }\end{array}$ \\
\end{tabular} & $\begin{array}{c}\text { Explanation } \\
\text { slides }\end{array}$ & PC, Projecter & Clicker & $\begin{array}{c}\mathrm{FE} \\
\text { problems }\end{array}$ & Commentary & Questionnaire & \begin{tabular}{|c|}
$\begin{array}{c}\text { Reply slide } \\
\text { for question }\end{array}$ \\
for
\end{tabular} & $\begin{array}{c}\text { Exercise } \\
\text { paper }\end{array}$ & Report & Investigation paper \\
\hline 1 & $\begin{array}{l}\text { To explain lecture plan and } \\
\text { what is FE?, To make the } \\
\text { students solve problems 1- } \\
20 \text { in } 2009\end{array}$ & \begin{tabular}{|l} 
To explain \\
lecture plan
\end{tabular} & What is FE? & $\begin{array}{l}\text { Projection of the } \\
\text { slide about } \\
\text { lecture plan and } \\
\text { FE }\end{array}$ & & \begin{tabular}{|l} 
Problems \\
$1-20$ in \\
2009
\end{tabular} & & & & & & $\begin{array}{l}\text { Degree of } \\
\text { recognition, } \\
\text { Awareness (pre) }\end{array}$ \\
\hline 2 & $\begin{array}{l}\text { Answer and description of } \\
\text { problems } 1-10 \text { in } 2009\end{array}$ & & \begin{tabular}{|l|}
$\begin{array}{l}\text { Problems 1-10 } \\
\text { in } 2009\end{array}$ \\
\end{tabular} & $\begin{array}{l}\text { Projection of the } \\
\text { explanatory slides }\end{array}$ & $\begin{array}{c}\text { Reply of degree of } \\
\text { understanding }\end{array}$ & & \begin{tabular}{|l|} 
Commentary \\
about problems \\
$1-10$ in 2009
\end{tabular} & $\begin{array}{l}\text { Questionnaire } \\
1-10\end{array}$ & & Exercise 1 & & \\
\hline 3 & $\begin{array}{l}\text { Answer and description of } \\
\text { problems 11-19 in } 2009\end{array}$ & & $\begin{array}{l}\text { Problems 11- } \\
19 \text { in } 2009\end{array}$ & $\begin{array}{l}\text { Projection of the } \\
\text { explanatory and } \\
\text { answer slides }\end{array}$ & $\begin{array}{c}\text { Reply of degree of } \\
\text { understanding }\end{array}$ & & \begin{tabular}{|l} 
Commentary \\
about problems \\
$11-20$ in 2009 \\
\end{tabular} & $\begin{array}{l}\text { Questionnaire } \\
11-20\end{array}$ & \begin{tabular}{|c|} 
Reply slide \\
for questions \\
$1-20$ \\
\end{tabular} & Exercise 2 & & \\
\hline 4 & $\begin{array}{l}\text { To make the students solve } \\
\text { problems } 21-60 \text { in } 2009\end{array}$ & & & & & $\begin{array}{l}\text { Problems } \\
21-60 \text { in } \\
2009\end{array}$ & & & $\begin{array}{c}\text { Reply slide } \\
\text { for questions } \\
11-20\end{array}$ & & & \\
\hline 5 & $\begin{array}{l}\text { Answer and description of } \\
\text { problems } 20-25 \text { in } 2009\end{array}$ & & $\begin{array}{l}\text { Problems 21- } \\
25 \text { in } 2009\end{array}$ & $\begin{array}{l}\text { Projection of the } \\
\text { explanatory and } \\
\text { answer slides }\end{array}$ & $\begin{array}{c}\text { Reply of degree of } \\
\text { understanding }\end{array}$ & & \begin{tabular}{|l} 
Commentary \\
about problems \\
$21-30$ in 2009
\end{tabular} & $\begin{array}{l}\text { Questionnaire } \\
20-25\end{array}$ & & Exercise 3 & & \\
\hline 6 & $\begin{array}{l}\text { Answer and description of } \\
\text { problems 26-36 in } 2009\end{array}$ & & $\begin{array}{l}\text { Problems 26- } \\
36 \text { in } 2009\end{array}$ & $\begin{array}{l}\text { Projection of the } \\
\text { explanatory and } \\
\text { answer slides }\end{array}$ & $\begin{array}{c}\begin{array}{c}\text { Reply of degree of } \\
\text { understanding }\end{array} \\
\end{array}$ & & \begin{tabular}{|l} 
Commentary \\
about problems \\
$31-40$ in 2009
\end{tabular} & $\begin{array}{l}\text { Questionnaire } \\
26-35\end{array}$ & \begin{tabular}{|l|}
$\begin{array}{l}\text { Reply slide } \\
\text { for questions } \\
20-25\end{array}$ \\
\end{tabular} & Exercise 4 & & \\
\hline 7 & $\begin{array}{l}\text { Answer and description of } \\
\text { problems } 37-46 \text { in } 2009\end{array}$ & & $\begin{array}{l}\text { Questions 37- } \\
46 \text { in } 2009\end{array}$ & $\begin{array}{l}\text { Projection of the } \\
\text { explanatory and } \\
\text { answer slides }\end{array}$ & $\begin{array}{c}\text { Reply of degree of } \\
\text { understanding }\end{array}$ & & $\begin{array}{l}\text { Commentary } \\
\text { about problems } \\
41-50 \text { in } 2009 \\
\end{array}$ & $\begin{array}{l}\text { Questionnaire } \\
36-46\end{array}$ & \begin{tabular}{|l|}
$\begin{array}{l}\text { Reply slide } \\
\text { for questions } \\
26-35\end{array}$ \\
\end{tabular} & Exercise 5 & & \\
\hline 8 & $\begin{array}{l}\text { Answer and description of } \\
\text { problems 47-53 in } 2009\end{array}$ & & $\begin{array}{l}\text { Problems 47- } \\
53 \text { in } 2009\end{array}$ & $\begin{array}{l}\text { Projection of the } \\
\text { explanatory and } \\
\text { answer slides }\end{array}$ & $\begin{array}{c}\begin{array}{c}\text { Reply of degree of } \\
\text { understanding }\end{array} \\
\end{array}$ & & \begin{tabular}{|l}
$\begin{array}{l}\text { Commentary } \\
\text { about problems } \\
51-60 \text { in } 2009\end{array}$ \\
\end{tabular} & $\begin{array}{l}\text { Questionnaire } \\
47-53\end{array}$ & \begin{tabular}{|l|} 
Reply slide \\
for questions \\
$37-46$
\end{tabular} & Exercise 6 & & \\
\hline 9 & $\begin{array}{l}\text { Answer and description of } \\
\text { problems 54-63 in } 2009\end{array}$ & & $\begin{array}{l}\text { Problems } 54- \\
63 \text { in } 2009\end{array}$ & $\begin{array}{l}\text { Projection of the } \\
\text { explanatory and } \\
\text { answer slides }\end{array}$ & $\begin{array}{c}\text { Answer to } \\
\text { problem and reply } \\
\text { of understanding } \\
\text { degree }\end{array}$ & $\begin{array}{l}\text { Problems } \\
61-63 \text { in } \\
2009\end{array}$ & $\begin{array}{l}\text { Commentary } \\
\text { about problems } \\
61-70 \text { in } 2009\end{array}$ & $\begin{array}{l}\text { Questionnaire } \\
54-63\end{array}$ & \begin{tabular}{|l|} 
Reply slide \\
for questions \\
$47-53$
\end{tabular} & Exercise 7 & & \\
\hline 10 & $\begin{array}{l}\text { Answer and description of } \\
\text { problems } 64-72 \text { in } 2009\end{array}$ & & $\begin{array}{l}\text { Problems 64- } \\
72 \text { in } 2009\end{array}$ & $\begin{array}{l}\text { Projection of the } \\
\text { explanatory and } \\
\text { answer slides }\end{array}$ & $\begin{array}{c}\text { Answer to } \\
\text { problem and reply } \\
\text { of understanding } \\
\text { degree }\end{array}$ & $\begin{array}{l}\text { Problems } \\
64-72 \text { in } \\
2009\end{array}$ & $\begin{array}{l}\text { Commentary } \\
\text { about problems } \\
61-63 \text { in } 2009\end{array}$ & $\begin{array}{l}\text { Questionnaire } \\
64-72\end{array}$ & \begin{tabular}{|l} 
Reply slide \\
for questions \\
$54-63$
\end{tabular} & Exercise 8 & & \\
\hline 11 & $\begin{array}{l}\text { Answer and description of } \\
\text { problems } 73-75 \text { in } 2009\end{array}$ & & $\begin{array}{l}\text { Problems } 73- \\
75 \text { in } 2009\end{array}$ & $\begin{array}{l}\text { Projection of the } \\
\text { explanatory and } \\
\text { answer slides }\end{array}$ & $\begin{array}{c}\text { Answer to } \\
\text { problem and reply } \\
\text { of understanding } \\
\text { degree }\end{array}$ & $\begin{array}{l}\text { Problems } \\
73-80 \text { in } \\
2009\end{array}$ & $\begin{array}{l}\text { Commentary } \\
\text { about problems } \\
64-72 \text { in } 2009\end{array}$ & $\begin{array}{l}\text { Questionnaire } \\
73-75\end{array}$ & \begin{tabular}{|l|} 
Reply slide \\
for questions \\
$64-72$
\end{tabular} & Exercise 9 & & \\
\hline 12 & $\begin{array}{l}\text { Answer and description of } \\
\text { problems } 76-80 \text { in 2009, To } \\
\text { make the students solve } \\
\text { problems } 1-40 \text { in } 2010\end{array}$ & & $\begin{array}{l}\text { Problems } 76- \\
80 \text { in } 2009\end{array}$ & $\begin{array}{l}\text { Projection of the } \\
\text { explanatory and } \\
\text { answer slides }\end{array}$ & $\begin{array}{c}\text { Reply of degree of } \\
\text { understanding }\end{array}$ & $\begin{array}{l}\text { Problems } \\
1-40 \text { in } \\
2010\end{array}$ & $\begin{array}{l}\text { Commentary } \\
\text { about problems } \\
73-80 \text { in } 2009\end{array}$ & $\begin{array}{l}\text { Questionnaire } \\
76-80\end{array}$ & \begin{tabular}{|l|} 
Reply slide \\
for questions \\
$73-75$
\end{tabular} & Exercise 10 & & \\
\hline 13 & $\begin{array}{l}\text { Answer and description of } \\
\text { problems } 1-10 \text { in } 2009\end{array}$ & & $\begin{array}{l}\begin{array}{l}\text { Problems 1-10 } \\
\text { in } 2010\end{array} \\
\end{array}$ & $\begin{array}{l}\text { Projection of the } \\
\text { explanatory and } \\
\text { answer slides }\end{array}$ & $\begin{array}{c}\text { Reply of degree of } \\
\text { understanding }\end{array}$ & & $\begin{array}{l}\text { Commentary } \\
\text { about problems } \\
1-10 \text { in } 2010\end{array}$ & $\begin{array}{l}\text { Questionnaire } \\
1-10\end{array}$ & \begin{tabular}{|l|}
$\begin{array}{l}\text { Reply slide } \\
\text { for questions } \\
76-80\end{array}$ \\
\end{tabular} & Exercise 11 & $\begin{array}{c}\text { Distribution } \\
\text { of flame of } \\
\text { report }\end{array}$ & \\
\hline 14 & $\begin{array}{l}\text { Answer and description of } \\
\text { problems } 10-20 \text { in } 2009\end{array}$ & & $\begin{array}{l}\text { Problems 10- } \\
20 \text { in } 2010\end{array}$ & $\begin{array}{l}\begin{array}{l}\text { Projection of the } \\
\text { explanatory and } \\
\text { answer slides }\end{array} \\
\end{array}$ & $\begin{array}{c}\text { Reply of degree of } \\
\text { understanding }\end{array}$ & & $\begin{array}{l}\text { Commentary } \\
\text { about problems } \\
11-20 \text { in } 2010\end{array}$ & $\begin{array}{l}\text { Questionnaire } \\
10-20\end{array}$ & \begin{tabular}{|l|} 
Reply slide \\
for questions \\
$1-9$
\end{tabular} & Exercise 12 & & \\
\hline 15 & $\begin{array}{l}\text { Answer and description of } \\
\text { problems 21-30 in 2009 }\end{array}$ & & $\begin{array}{l}\text { Problems 21- } \\
30 \text { in } 2010\end{array}$ & $\begin{array}{l}\text { Projection of the } \\
\text { explanatory and } \\
\text { answer slides }\end{array}$ & $\begin{array}{c}\begin{array}{c}\text { Reply of degree of } \\
\text { understanding }\end{array} \\
\end{array}$ & & \begin{tabular}{|l} 
Commentary \\
about problems \\
$21-30$ in 2010
\end{tabular} & $\begin{array}{l}\text { Questionnaire } \\
21-30\end{array}$ & \begin{tabular}{|l|}
$\begin{array}{l}\text { Reply slide } \\
\text { for questions } \\
10-20\end{array}$ \\
\end{tabular} & & & $\begin{array}{l}\text { Degree of } \\
\text { recognition, } \\
\text { Awareness (post) }\end{array}$ \\
\hline
\end{tabular}


opinions to a bulletin board and browsing them; and (6) sending question mail.

\subsection{Use of the clickers}

The introduction of clickers into the class, through bidirectional and thus more effective presentations, improved the lectures, which conventionally had tended to be rather one-way. The students could easily use the clickers as they only needed to press the key of the number they had selected on a card terminal (keypad) that resembles a $\mathrm{TV}$ remote control. The results of all the students could then be immediately displayed on-site. The clickers were used to identify their degree of understanding of the explanation, and their answers to the problems, and the results instantly graphed. A similar system that utilizes cell phones includes the problems of support, which is to have to pay for the packets transmitted, and restrictions with regard to the number of simultaneous connections. A clicker is therefore better in that they involve no such problems.

This study utilized the 3eAnalyzer of Kimura Information Technology as the clickers [5]. With this system a receiver inserted into the USB port of a PC is used to receive the answers from the keypads.

The 3eAnalyzer supports six types of slides: questionnaire, percentage of correct answers, score, votes, sign-in, and numbers, with the following three being used in the class:

(1) Student attendance check

Using the number slides attendance was checked by inputting 4 digits that comprised the 2 digits of their year of entry and the 2 digits of their student number.

(2) Reply on the degree of understanding of the explanation

Using the questionnaire slides the students were asked to reply with regard to their degree of understanding using the clickers after the explanation. (3) Answers to problems

Using the slides for the percentage of correct answers the students were asked to solve multiplechoice question with four choices during class, and then answer them using the clickers.

\section{Results of analysis}

In a class involving exercises from the subject of information a survey on the degree of term recognition was used to identify the changes in the student's level of knowledge [6]. An attitude survey on their abilities was conducted to pinpoint the changes in their attitude. The survey data was then analyzed via significance tests and the results are reported in this section. The students were asked to pinpoint the activities that helped improve their attitude to the right of the rating scale value of the attitude survey. Cross tabulation was conducted on the number of activities using the attitude row and activity column. The tabulation table was then subjected to cluster analysis, and attitude and activities each was classified into several clusters. With the table resulting from tabulating the attitude and activity clusters the $\mathrm{x}^{2}$ test was used to identify which activities helped improve attitude based on the significance of the degree of deviation.

Hereafter, it can be considered that there was a significant difference when the significance level in the significance test was $5 \%$ or larger. The codes $\mathrm{m}$, $\mathrm{SD}, \mathrm{t}$, and $\mathrm{p}$ indicate the mean, standard deviation, test statistic, and $\mathrm{p}$ value, respectively.

\subsection{Changes in the degree of recognition of terms related to the class}

Regarding the 75 terms related to the content of the class, as listed in Table 2, the degree of recognition was investigated twice, or both before (1st week) and after (15th week) the class. The 75 terms were selected as being important terms related to the knowledge tested in the Fundamental Information Technology Engineer Examination.

The degree of term recognition was rated using 3 stages: 1. No knowledge, 2. No detailed knowledge but sounds familiar, and 3. Familiar knowledge. The mean degrees of the term recognition both before and after the class were 2.1 and 2.4 , respectively. The numbers of student respondents to the survey before and after the class were 34 and 43, respectively.

As revealed in the bottom row of Table 2 the t-test conducted for all 75 terms both before and after the class showed significant differences. The significantly higher degree of term recognition after the class than before indicated that the overall knowledge of the students had improved.

The results of the t-test on the degree of recognition regarding each term both before and after the class revealed significant differences with the following 13 terms: (36), (41), (48), (50), (52), (53), (54), (55), (64), (65), (67), (74), and (75). A tendency for significant differences was observed with the following 7 terms: (37), (49), (56), (57), (58), (61), and (63). The results led to the supposition that their knowledge had increased with the aforementioned 13 terms, and that there was a tendency for their knowledge to have increased with the latter 7 terms.

The degree of recognition before the class was already 2 or higher for most of the remaining 55 terms, and for which neither significant differences nor a tendency toward significant differences were observed, thus indicating that they at least fell into "No detailed knowledge but sounding familiar," and thus the consideration that there was little room to grow and that it resulted in no significant difference. 
Table 2. Significance test on degree of term recognition related to lectures

\begin{tabular}{|c|c|c|c|c|c|c|c|c|}
\hline \multirow{2}{*}{\begin{tabular}{|l|}
$\frac{8}{0}$ \\
$\frac{0}{4}$ \\
\end{tabular}} & \multirow{2}{*}{ No } & \multirow{2}{*}{ Technical terms } & \multicolumn{2}{|c|}{ Before } & \multicolumn{2}{|c|}{ After } & \multicolumn{2}{|c|}{ t-test } \\
\hline & & & $\mathrm{m}$ & SD & $\mathrm{m}$ & SD & $\mathrm{t}$ & $\mathrm{p}$ \\
\hline & 1 & Discrete mathematics & 2.4 & 1.1 & 2.5 & 1.3 & 0.3 & \\
\hline & 2 & Applied mathematics & 2.0 & 1.0 & 2.4 & 1.2 & 1.4 & \\
\hline & 3 & $\begin{array}{l}\text { Theory of information, communication, } \\
\text { and measurement control }\end{array}$ & 1.9 & 1.0 & 2.1 & 1.2 & 0.7 & \\
\hline & 4 & Data structure & 2.5 & 1.2 & 2.7 & 1.4 & 0.6 & \\
\hline & 5 & Algorithm & 2.8 & 1.2 & 2.8 & 1.4 & 0.2 & \\
\hline & 6 & Programming & 2.9 & 1.2 & 2.9 & 1.4 & 0.2 & \\
\hline & 7 & Programming language & 2.8 & 1.2 & 2.9 & 1.4 & 0.2 & \\
\hline & 8 & Processor & 2.4 & 1.1 & 2.5 & 1.3 & 0.3 & \\
\hline & 9 & Memory & 2.6 & 1.1 & 2.7 & 1.4 & 0.6 & \\
\hline & 10 & Bus & 2.5 & 1.1 & 2.6 & 1.3 & 0.4 & \\
\hline & 11 & Input and output device & 2.5 & 1.2 & 2.6 & 1.3 & 0.3 & \\
\hline & 12 & Input-output unit & 2.7 & 1.2 & 2.8 & 1.4 & 0.3 & \\
\hline & 13 & Constitution of the system & 2.5 & 1.1 & 2.5 & 1.3 & 0.1 & \\
\hline & 14 & Performance index of the system & 2.1 & 1.0 & 2.3 & 1.2 & 0.9 & \\
\hline & 15 & OS & 2.8 & 1.2 & 2.8 & 1.4 & 0.2 & \\
\hline & 16 & Middleware & 2.4 & 1.1 & 2.6 & 1.3 & 0.6 & \\
\hline & 17 & File system & 2.3 & 1.1 & 2.5 & 1.3 & 0.5 & \\
\hline & 18 & Development tool & 2.3 & 1.1 & 2.6 & 1.3 & 0.9 & \\
\hline & 19 & Open source & 2.4 & 1.1 & 2.7 & 1.3 & 0.9 & \\
\hline & 20 & Hardware & 2.6 & 1.2 & 2.9 & 1.4 & 1.0 & \\
\hline & 21 & Human interface & 2.1 & 1.0 & 2.5 & 1.3 & 1.4 & \\
\hline & 22 & Multimedia & 2.4 & 1.1 & 2.7 & 1.3 & 0.9 & \\
\hline 응 & 23 & Method of the database & 2.0 & 1.0 & 2.4 & 1.2 & 1.3 & \\
\hline 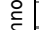 & 24 & Design of the database & 2.0 & 1.0 & 2.4 & 1.2 & 1.5 & \\
\hline ड़ & 25 & Operation of the database & 2.0 & 1.0 & 2.4 & 1.2 & 1.4 & \\
\hline & 26 & Transaction processing & 2.0 & 1.0 & 2.2 & 1.2 & 0.7 & \\
\hline & 27 & Network system & 2.3 & 1.1 & 2.6 & 1.3 & 1.0 & \\
\hline & 28 & Communication and control & 2.3 & 1.1 & 2.5 & 1.3 & 0.6 & \\
\hline & 29 & Protocol & 2.5 & 1.1 & 2.7 & 1.4 & 0.7 & \\
\hline & 30 & Network management & 2.3 & 1.1 & 2.6 & 1.3 & 1.0 & \\
\hline & 31 & Information security & 2.5 & 1.1 & 2.7 & 1.4 & 0.7 & \\
\hline & 32 & Security management & 2.5 & 1.1 & 2.6 & 1.3 & 0.3 & \\
\hline & 33 & Security technology evaluation & 2.2 & 1.1 & 2.3 & 1.2 & 0.1 & \\
\hline & 34 & Security countermeasures & 2.5 & 1.2 & 2.6 & 1.3 & 0.2 & \\
\hline & 35 & $\begin{array}{l}\text { Security implementations } \\
\text { technology }\end{array}$ & 2.1 & 1.0 & 2.3 & 1.2 & 0.8 & \\
\hline & 36 & Definition of system requirements & 1.7 & 0.9 & 2.2 & 1.2 & 2.2 & * \\
\hline & 37 & System method design & 1.8 & 0.9 & 2.3 & 1.2 & 1.7 & + \\
\hline & 38 & Various test processes & 2.0 & 1.0 & 2.3 & 1.3 & 1.1 & \\
\hline & 39 & System maintenance & 2.0 & 1.0 & 2.3 & 1.2 & 1.2 & \\
\hline & 40 & $\begin{array}{l}\text { A development process and } \\
\text { technique }\end{array}$ & 1.9 & 1.0 & 2.3 & 1.2 & 1.4 & \\
\hline & 41 & $\begin{array}{l}\text { Intellectual property application } \\
\text { management }\end{array}$ & 1.8 & 1.0 & 2.4 & 1.3 & 2.0 & * \\
\hline & 42 & $\begin{array}{l}\text { Development environment } \\
\text { management }\end{array}$ & 1.8 & 1.0 & 2.1 & 1.2 & 1.3 & \\
\hline & 43 & $\begin{array}{l}\text { Configuration management and } \\
\text { change management }\end{array}$ & 1.8 & 0.9 & 2.1 & 1.1 & 1.3 & \\
\hline 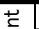 & 444 & Project management & 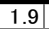 & 0.9 & 2.2 & $\overline{1.2}$ & 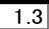 & \\
\hline 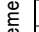 & 45 & Operative design and tool & 2.0 & 1.0 & 2.3 & 1.2 & 0.9 & \\
\hline 离 & 46 & Service support & 1.9 & 1.0 & 2.2 & 1.2 & 1.2 & \\
\hline$\stackrel{0}{\pi}$ & 47 & Service management construction & 1.8 & 0.9 & 2.2 & 1.2 & 1.5 & \\
\hline & 48 & EDP audit and internal control & 1.6 & 0.9 & 2.3 & 1.2 & 2.5 & $*$ \\
\hline & 49 & Information system strategy & \begin{tabular}{|c|}
1.8 \\
\end{tabular} & 0.9 & 2.3 & 1.2 & 1.7 & + \\
\hline & 50 & Business processes & 1.8 & 0.9 & 2.3 & 1.2 & 2.2 & * \\
\hline & 51 & Solution business & 1.6 & 0.9 & 1.9 & 1.1 & 1.4 & \\
\hline & 52 & Systematization plan & 1.7 & 0.9 & 2.3 & 1.2 & 2.1 & * \\
\hline & 53 & Definition of requirements & 1.5 & 0.9 & 2.3 & 1.3 & 3.2 & ** \\
\hline & 54 & $\begin{array}{l}\text { A procurement plan and } \\
\text { enforcement }\end{array}$ & 1.5 & 0.9 & 2.2 & 1.2 & 2.7 & ** \\
\hline & 55 & Corporate strategy technique & 1.7 & 0.9 & 2.4 & 1.3 & 2.7 & ** \\
\hline & 56 & Marketing & 2.2 & 1.1 & 2.6 & 1.3 & 1.7 & + \\
\hline & 57 & A strategy and an aim, evaluation & 2.0 & 1.0 & 2.4 & 1.3 & 1.7 & + \\
\hline & 58 & Management system & 1.8 & 1.0 & 2.3 & 1.2 & 1.8 & + \\
\hline & 59 & $\begin{array}{l}\text { Drafting of the technology } \\
\text { development strategy }\end{array}$ & 1.7 & 0.9 & 2.0 & 1.1 & 1.4 & \\
\hline $\overrightarrow{0}$ & 60 & Technology development plan & 1.8 & 1.0 & 2.2 & 1.2 & 1.5 & \\
\hline & 61 & Business system & 1.9 & 1.0 & 2.3 & 1.2 & 1.7 & + \\
\hline 离 & 62 & Engineering system & 1.9 & 1.0 & 2.3 & 1.2 & 1.3 & \\
\hline & 63 & E-business & 1.9 & 1.0 & 2.4 & 1.3 & 1.8 & + \\
\hline & 64 & Public welfare apparatus & 1.5 & 0.8 & 1.9 & 1.1 & 2.0 & * \\
\hline & 65 & Industrial instrument & 1.5 & 0.8 & 1.9 & 1.1 & 2.0 & * \\
\hline & 66 & Management & 2.1 & 1.1 & 2.3 & 1.2 & 0.9 & \\
\hline & 67 & Organization theory & 1.6 & 0.9 & 2.1 & 1.2 & 2.1 & * \\
\hline & 68 & OR and IE & 1.5 & 0.9 & 1.7 & 1.0 & 0.8 & \\
\hline & 69 & Accounts and financial affairs & 1.9 & 1.0 & 2.3 & 1.2 & 1.5 & \\
\hline & 70 & Intellectual property rights & 2.2 & 1.1 & 2.5 & 1.3 & 1.1 & \\
\hline & 71 & Security connection & 2.0 & 1.1 & 2.5 & 1.3 & 1.5 & \\
\hline & 72 & Labor relation & 1.8 & 0.9 & 2.2 & 1.2 & 1.6 & \\
\hline & 73 & Dealings relation & 1.7 & 0.9 & 2.1 & 1.1 & 1.6 & \\
\hline & 74 & Other relation laws & 1.5 & 0.8 & 2.1 & 1.1 & 2.2 & * \\
\hline & 75 & Standardization-related & 1.5 & 0.9 & 2.1 & 1.1 & 2.3 & $*$ \\
\hline & & Average & 2.1 & 1.1 & 2.4 & 1.2 & 10.2 & *** \\
\hline
\end{tabular}

\subsection{Changes in rating scale value of attitude related to abilities}

To identify attitude related to the abilities pertaining to the 34 items listed in Table 3 a survey before the class was conducted during the 1st class and a survey after the class during the 15th class [6]. The rating scale values were provided in the 9 stages of "1. Not at all, 3. Very slightly, 5. A little, 7. Considerably and 9. Extremely aware." The numbers of students that answered the surveys both before and after the class were 34 and 44, respectively.

The mean rating scale values for all the 34 items before and after the class were 4.4 and 5.3, respectively. Significant differences were observed for all 34 items between the rating scale values before and after the class as a result of the t-test. This then led to the discovery that the overall attitude related to abilities had improved.

Table 3 provides the results of the t-test of the rating scale values for each attitude item related to abilities before and after the class. Significant differences were observed in the t-test between the rating scale values before and after the class with the following 25 terms: (2), (4), (6)-(10), (13), (14), (16)(18), (20)-(29), and (31)-(33). A tendency toward significant differences was observed with the following 5 items: (3), (5), (12), (15), and (19).

The 30 items regarding attitude related to abilities showing significant differences or a tendency for a significant difference revealed that attitude had improved for most of the 34 items. The remaining 4 items with no significant difference or a tendency for a significant difference were (1), (11), (30), and (34). It can be surmised from this that "(1) interest in computers, (30) interest in this field, and (34) willingness to take the Fundamental Information Technology Engineer Examination (FE)" had no significant differences due to there being very little room for growth as their rating scale values before the class were relatively higher than those of other items. The willingness to take the FE, in particular, was already high at the beginning, and it can be assumed that (34) did not change very much even with the help of the class. It can be also surmised that "(11) Ability to analyze information" did not grow as there were no such activities that may have nurtured this ability in the class.

\subsection{Categories of students determined by cluster analysis for attitude related to ability}

When students replied the rating value about attitude of 34 items at the post survey, they were required to enter the activities which were useful for improvement of each attitude among 30 activities at the right of the column where the degree of attitude was entered. The number of respondents to questionnaires is 44 persons. The total enumerated 
was 2225 . The cross table was created with activity as a column, with the attitude as a row. The activities useful for improving the attitude related to abilities were totaled by making a $34 \times 30$ cross table. In the following, the numbers with a parenthesis express the number of attitude, and Arabic figures express the number of activity.

As many cells in the table had less frequency than five and the number of activities per cell was 2.18 on average, $\chi^{2}$ test cannot be conducted if nothing is done. Then it was considered to take some cells in similar attitude and similar activities respectively. First, the cluster analysis was conducted about the cross table using Ward's method with activity as a variable, with the attitude as a case. As a result, the attitude was classified into next four groups I to IV as shown in left column of Table 3 . The frequency of activities enumerated for each attitude is shown in right of Table 3 .

The group I consists of nine attitudes of (31), (32), (33), (34), (30), (1), (2), (3), and (4). These numbers are the attitude shown in Table 3 . As the number of activities enumerated for these attitudes is over average number and especially many activities are enumerated for attitudes (30)-(34), (1) and (2), it was referred to as "Knowledge of FE and understanding of computers".

In the same way, the group II consists of 15 attitudes of (21), (27), (7), (5), (26), (6), (29), (8), (9), (22), (28), (24), (25), (10), and (11). Because particularly many activities are enumerated for attitudes (7), (28), (21), (22), (26), and (27), it was referred to as "Attitude related to thinking, and the pursuit, implementation and deepening of knowledge and understanding".

The group III consists of three attitudes of (16), (17) and (23). Since activities with similar frequency are enumerated for these attitudes, it was referred to as "Attitude related to cooperation, questioning and communication".

The group IV consists of seven attitudes of (14), (15), (19), (12), (13), (18), and (20). Since relativelynumerous activities are enumerated for attitudes (12), (18), (20), and (14), it was referred to as "Attitude related to expression, evaluation and correction".

Table 3. Results of significance test on attitude related to abilities and clusters of attitude

\begin{tabular}{|c|c|c|c|c|c|c|c|c|c|}
\hline \multirow{2}{*}{$\begin{array}{c}\text { Cluster of } \\
\text { attitude }\end{array}$} & \multirow{2}{*}{ Attitude related to ability } & \multicolumn{2}{|c|}{ Before } & \multicolumn{2}{|c|}{ After } & \multicolumn{2}{|c|}{ t-test } & \multirow{2}{*}{\begin{tabular}{|l|} 
Frequ \\
ency
\end{tabular}} & \multirow{2}{*}{ Sum } \\
\hline & & $\mathrm{m}$ & SD & $\mathrm{m}$ & SD & $t$ & $p$ & & \\
\hline \multirow{9}{*}{$\begin{array}{l}\text { I. Knowledge of } \\
\text { FE and } \\
\text { understanding } \\
\text { of computers }\end{array}$} & (31) Knowledge about the technology system & 3.7 & 2.2 & 4.9 & 2.1 & 2.4 & * & 78 & \multirow{9}{*}{691} \\
\hline & (32) Knowledge about the management system & 3.5 & 1.7 & 4.9 & 1.9 & 3.4 & *** & 77 & \\
\hline & (33) Knowledge about the strategy system & 3.4 & 1.8 & 4.8 & 1.9 & 3.4 & $* * *$ & 75 & \\
\hline & (34) Volition which takes a FE & 6.0 & 2.6 & 6.7 & 2.4 & 1.2 & & 79 & \\
\hline & (30) Interest and concern with this field & 5.6 & 2.1 & 6.3 & 2.4 & 1.3 & & 91 & \\
\hline & (1) Interest and concern with computers & 6.3 & 2.0 & 6.9 & 2.0 & 1.3 & & 79 & \\
\hline & ( 2) Understanding of computers & 4.5 & 1.7 & 5.4 & 1.6 & 2.4 & * & 81 & \\
\hline & ( 3) Computer operating skill & 4.5 & 1.5 & 5.1 & 1.6 & 1.8 & + & 61 & \\
\hline & ( 4) Computer utilization method and expansion of scene & 4.5 & 1.9 & 5.7 & 1.5 & 3.1 & ** & 70 & \\
\hline \multirow{15}{*}{$\begin{array}{l}\text { II. Attitude } \\
\text { related to } \\
\text { thinking, and } \\
\text { the pursuit, } \\
\text { implementation } \\
\text { and deepening } \\
\text { of knowledge } \\
\text { and } \\
\text { understanding }\end{array}$} & (21) Ability to pursue things thoroughly and spirit of inquiry & 4.7 & 1.5 & 5.5 & 1.5 & 2.5 & $*$ & 79 & \multirow{15}{*}{1059} \\
\hline & (27) Ability of composing knowledge and creating knowledge & 4.3 & 1.6 & 5.1 & 1.7 & 2.0 & * & 78 & \\
\hline & ( 7) Deepening of understanding of learned knowledge & 4.3 & 1.3 & 5.4 & 1.4 & 3.4 & $* * *$ & 82 & \\
\hline & (5) Ability to set a theme and problem finding ability & 4.4 & 1.7 & 5.0 & 1.6 & 1.7 & + & 69 & \\
\hline & (26) Problem-solving ability & 4.4 & 1.6 & 5.2 & 1.6 & 2.1 & $*$ & 78 & \\
\hline & ( 6) Ability to plan and to project things & 4.4 & 1.2 & 5.1 & 1.7 & 2.2 & * & 60 & \\
\hline & (29) Creativity and ability to create & 4.6 & 1.8 & 5.5 & 1.8 & 2.2 & $*$ & 65 & \\
\hline & ( 8) Ability to study and learn independently & 4.3 & 1.4 & 5.6 & 1.8 & 3.2 & *** & 71 & \\
\hline & (9) Information collection ability and investigation capability & 4.8 & 1.7 & 5.6 & 1.7 & 2.0 & * & 68 & \\
\hline & (22) Ability to perform, practice and execute & 4.3 & 1.8 & 5.2 & 1.5 & 2.4 & * & 78 & \\
\hline & (28) Ability to think independently, thinking power, and power of ideas & 4.7 & 1.8 & 5.6 & 1.5 & 2.5 & $*$ & 80 & \\
\hline & (24) Sense of fulfillment and satisfaction & 4.5 & 1.8 & 5.7 & 1.7 & 2.9 & ** & 69 & \\
\hline & (25) Sense of accomplishment and sense of achievement & 4.3 & 1.7 & 5.4 & 1.9 & 2.5 & * & 67 & \\
\hline & (10) Ability to sort out and sum up information and data & 4.4 & 1.8 & 5.4 & 1.7 & 2.3 & * & 55 & \\
\hline & (11) Information analysis ability & 4.5 & 1.5 & 5.1 & 1.6 & 1.6 & & 60 & \\
\hline \multirow{3}{*}{$\begin{array}{l}\text { III. Attitude } \\
\text { related to } \\
\text { cooperation, } \\
\text { questioning and } \\
\text { communication }\end{array}$} & (16) Ability to listen to others and to raise questions to others & 4.3 & 1.6 & 5.1 & 1.6 & 2.0 & * & 50 & \multirow{3}{*}{153} \\
\hline & (17) Communication ability & 3.9 & 1.8 & 5.1 & 1.8 & 2.7 & ** & 44 & \\
\hline & (23) Ability to co-operate and to learn concertedly & 4.4 & 1.7 & 5.3 & 1.9 & 2.1 & * & 59 & \\
\hline \multirow{7}{*}{$\begin{array}{l}\text { IV. Attitude } \\
\text { related to } \\
\text { expression, } \\
\text { evaluation and } \\
\text { correction }\end{array}$} & (14) Ability to talk to and explain to others comprehensively & 3.9 & 1.6 & 4.7 & 1.8 & 2.2 & * & 47 & \multirow{7}{*}{322} \\
\hline & (15) Presentation ability & 3.9 & 1.9 & 4.6 & 1.6 & 1.8 & + & 44 & \\
\hline & (19) Ability to evaluate properly what has been figured out by others & 4.8 & 1.7 & 5.5 & 1.7 & 1.7 & + & 37 & \\
\hline & (12) Ability to express one's own thought by sentences & 4.4 & 1.7 & 5.1 & 1.8 & 1.7 & + & 54 & \\
\hline & (13) Ability of expressing own thought other than in sentences & 4.0 & 1.8 & 4.9 & 1.7 & 2.3 & * & 42 & \\
\hline & (18) Ability to self-evaluate properly what is figured out by oneself & 4.4 & 1.5 & 5.2 & 1.6 & 2.0 & * & 50 & \\
\hline & (20) Ability to correct and improve what has been figured out by oneself & 4.4 & 1.6 & 5.4 & 1.8 & 2.3 & $*$ & 48 & \\
\hline & Average & 4.4 & 1.8 & 5.3 & 1.8 & 12.7 & *** & 2225 & 2225 \\
\hline
\end{tabular}




\subsection{Categories of activities determined by cluster analysis for attitude}

Secondly, the cluster analysis was conducted about the same cross table using Ward's method with attitude as a variable, with the activity as a case. As a result, the activities were classified into next five groups 1 to 5 as shown in left column of Table 4. The frequency of each activity is shown in right of Table 4.

The group 1 consists of the following 16 activities: $28,29,27,13,15,18,20,12,14,10,30,9,23,19,25$ and 26. Since activities of 25,26 , and 12 were enumerated much, it was referred to as "activities related to rewriting reports and answering with clickers." The number enumerated about these activities is 412 .

The group 2 consists of the following seven activities: 7, 8, 17, 16, 2, 4, and 24. Since activities of $24,2,16,7$, and 8 were enumerated much, it was referred to as "activities related to report preparation

Table 4. Categories for activities and the frequency

\begin{tabular}{|c|c|c|c|}
\hline $\begin{array}{c}\text { Cluster of } \\
\text { activity }\end{array}$ & Activity & \begin{tabular}{|l|} 
Frequ \\
ency
\end{tabular} & Sum \\
\hline \multirow{16}{*}{$\begin{array}{l}\text { 1. Activities } \\
\text { related to } \\
\text { rewriting reports } \\
\text { and answering } \\
\text { with clickers }\end{array}$} & 28. Writing on the message board & 6 & \multirow{16}{*}{412} \\
\hline & 29. Reading the answer to bulletin boards & 4 & \\
\hline & 27. Asking a question by emails & 2 & \\
\hline & $\begin{array}{l}\text { 13. Watching the distribution counted by } \\
\text { clickers }\end{array}$ & 8 & \\
\hline & 15. Hearing the answer to questions & 19 & \\
\hline & 18. Using Word & 27 & \\
\hline & 20. Evaluating abilities and attitudes & 13 & \\
\hline & 12. Replying answer using clickers & 45 & \\
\hline & 14. Filling out questionnaire & 36 & \\
\hline & $\begin{array}{l}\text { 10. Watching answer distribution every } \\
\text { problem in morning }\end{array}$ & 23 & \\
\hline & 30. others & 25 & \\
\hline & $\begin{array}{l}\text { 09. Watching self's score of the problems } \\
\text { in morning }\end{array}$ & 33 & \\
\hline & $\begin{array}{l}\text { 23. Arranging so as to understand what to } \\
\text { examine }\end{array}$ & 35 & \\
\hline & 19. Using Excel & 27 & \\
\hline & 25. Polishing a report and rewrite it. & 57 & \\
\hline & 26. Completing reports. & 52 & \\
\hline \multirow{7}{*}{$\begin{array}{l}\text { 2. Activities } \\
\text { related to report } \\
\text { preparation and } \\
\text { learning through } \\
\text { e-learning }\end{array}$} & 07. Learning using distribution documents & 77 & \multirow{7}{*}{571} \\
\hline & $\begin{array}{l}\text { 08. Answering problems in morning during } \\
\text { classes }\end{array}$ & 76 & \\
\hline & 17. Learning by a problem of e-learning & 69 & \\
\hline & 16. Learning using class slides & 78 & \\
\hline & $\begin{array}{l}\text { 02. Getting a broad understanding of the } \\
\text { lecture }\end{array}$ & 87 & \\
\hline & $\begin{array}{l}\text { 04. Asking the professor questions about } \\
\text { lecture topics }\end{array}$ & 66 & \\
\hline & 24. Writing reports & 118 & \\
\hline $\begin{array}{l}\text { 3. Activities that } \\
\text { involve } \\
\text { questioning } \\
\text { friends }\end{array}$ & $\begin{array}{l}\text { 03. Asking friends questions about lecture } \\
\text { topics }\end{array}$ & 120 & 120 \\
\hline \multirow{5}{*}{$\begin{array}{l}\text { 4. Activities that } \\
\text { involve listening } \\
\text { to explanations, } \\
\text { preparation, } \\
\text { review, and study }\end{array}$} & $\begin{array}{l}\text { 21. Studying for the final exam using the } \\
\text { commentary distributed }\end{array}$ & 106 & \multirow{5}{*}{639} \\
\hline & 22. Studying for the final exam & 100 & \\
\hline & 06. Reviewing & 133 & \\
\hline & $\begin{array}{l}\text { 11. Hearing the commentary of the } \\
\text { problem in morning during class }\end{array}$ & 120 & \\
\hline & 05. Preparing & 180 & \\
\hline $\begin{array}{l}\text { 5. Activities that } \\
\text { involve listening } \\
\text { to lectures }\end{array}$ & 01. Listening to lectures & 483 & 483 \\
\hline & Total & 2225 & 2225 \\
\hline
\end{tabular}

and learning through e-learning." The number enumerated about these activities is $\mathbf{5 7 1}$.

The group 3 consists of only one activity 3 . Since it is "asking friends questions about lecture topics," it was referred to as "activities that involve questioning friends." The number enumerated about this activity is 120 .

The group 4 consists of the following five activities: $21,22,6,11$, and 5 . It was referred to as "activities that involve listening to explanations, preparation, review, and study." The number enumerated about this activity is 639 .

The group 5 consists of only one activity " 1 . Listening to lectures." It was referred to as "activities that involve listening to lectures." The number enumerated about this activity is 483 .

\subsection{Activity useful for improving the attitude related to ability}

Activities enumerated much were as follows: " 1 . listening to lectures, 5. preparing, 6. reviewing, 3. asking friends questions about lecture topics, 11. hearing the commentary of the problem in morning during class, 24 . writing a report, and 21 . studying for the final exam using the commentary distributed."

It was suggested that students gave a reply that the activities related to " 1 . listening to lectures" and " 24 . writing a report" are helpful for improving the attitude related to ability. Thus, it is helpful for raising attitude related to expression, evaluation and correction to write the report which five calculation problems are answered among the problems in morning.

The frequency in cells is added up for every cluster about attitude and an activity. Results are shown in the upper left of Table 5. Each expected frequency of cell in the upper right of Table 5 was more than 8.3 and no cell has less frequency than five. Therefore, this table was considered to be analyzed as $4 \times 5$ contingency table. The $\chi^{2}$ test was conducted for this table. As a result, the frequency deflection was recognized $\left(\chi^{2}(12)=377.6, p<.001\right)$. Therefore, a result of residual analysis is shown in the lower left of Table 5. Significant deflection with positive residual is shown by a $*$ mark in the cell of the lower right of Table 5. Activities useful for improving the attitude are explained by significant cells with greater frequency in the following.

The activity group, "1. Activities related to rewriting reports and answering with clickers," is significantly useful for improving the attitude group, "IV. Attitude related to expression, evaluation and correction."

The activity group, " 2 . Activities related to report preparation and learning through e-learning," tends to significantly raise the attitude group, "IV. Attitude 
related to expression, evaluation and correction."

The activity group, "3. Activities that involve questioning friends," are significantly useful for improving the attitude group, "III. Attitude related to cooperation, questioning and communication" and "IV. Attitude related to expression, evaluation and correction."

The activity group, "4. Activities that involve listening to explanations, preparation, review, and study," is significantly useful for improving the attitude groups, "II. Attitude related to thinking, and the pursuit, implementation and deepening of knowledge and understanding."

The activity group, "5. Activities that involve listening to lectures," are significantly useful for improving the attitude group, "I. Knowledge of FE and understanding of computers."

Table 5. $\chi 2$ test and residual analysis about the cluster of attitude and activity

\begin{tabular}{|c|c|c|c|c|c|c|c|c|c|c|c|}
\hline \multirow[b]{2}{*}{$\begin{array}{l}\text { Clusters of } \\
\text { activities and attitude }\end{array}$} & \multicolumn{6}{|c|}{ Observed frequency } & \multicolumn{5}{|c|}{ Expected frequency } \\
\hline & 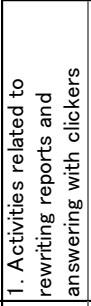 & 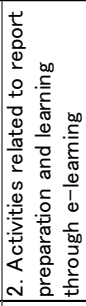 & 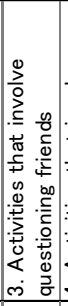 & 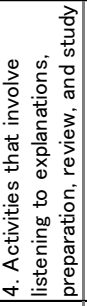 & 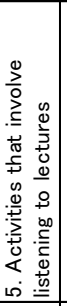 & 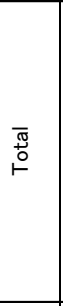 & 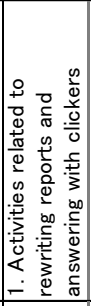 & 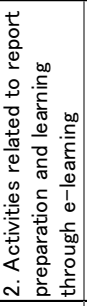 & 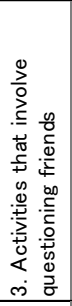 & 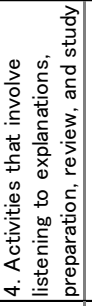 & 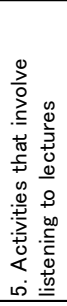 \\
\hline I. Knowledge of $\mathrm{FE}$ and understanding of computers & 92 & 165 & 28 & 203 & 203 & 691 & 128.0 & 177.3 & 37.3 & 198.4 & 150.0 \\
\hline $\begin{array}{l}\text { II. Attitude related to thinking, and the pursuit, implementation and } \\
\text { deepening of knowledge and understanding }\end{array}$ & 184 & 267 & 21 & 394 & 193 & 1059 & 196.1 & 271.8 & 57.1 & 304.1 & 229.9 \\
\hline III. Attitude related to cooperation, questioning and communication & 15 & 43 & 42 & 16 & 37 & 153 & 28.3 & 39.3 & 8.3 & 43.9 & 33.2 \\
\hline IV. Attitude related to expression, evaluation and correction & 121 & 96 & 29 & 26 & 50 & 322 & 28.3 & 39.3 & 8.3 & 43.9 & 33.2 \\
\hline \multirow[t]{2}{*}{ Total } & 412 & 571 & 120 & 639 & 483 & 2225 & 412.0 & 571.0 & 120.0 & 639.0 & 483.0 \\
\hline & \multicolumn{5}{|c|}{ Adjusted residual } & & \multicolumn{5}{|c|}{ Significance probability } \\
\hline I. Knowledge of FE and understanding of computers & -4.2 & -1.3 & -1.9 & 0.5 & 5.9 & & & & & & $* * *$ \\
\hline $\begin{array}{l}\text { II. Attitude related to thinking, and the pursuit, implementation and } \\
\text { deepening of knowledge and understanding }\end{array}$ & -1.3 & -0.5 & -6.8 & 8.4 & -3.8 & & & & & $* * *$ & \\
\hline III. Attitude related to cooperation, questioning and communication & -2.9 & 0.7 & 12.5 & -5.2 & 0.8 & & & & $* * *$ & & \\
\hline IV. Attitude related to expression, evaluation and correction & 9.5 & 1.8 & 3.1 & -8.9 & -2.9 & & $* * *$ & + & $* *$ & & \\
\hline
\end{tabular}

\section{Discussion}

Because the significantly higher degree of term recognition after the class than before indicated that the overall knowledge of the students had improved as explained in section 3.1, one of the purposes of this class was to "deepen understanding of knowledge from information technology." The overall knowledge of the students did increase, and thus it can be surmised that their knowledge related to the Fundamental Information Technology Engineer Examination had improved.

Twenty technical terms improved as shown in Table 2. The recognition degree before the class was already 2 or higher for most of the remaining 55 terms, and for which neither significant differences nor a tendency toward significant differences were observed. It indicates that they at least fell into "No detailed knowledge but sounding familiar," and thus it is considered that there was little room to grow and that it resulted in no significant difference.

As shown in Table 2, ratio of technical terms whose degree change was recognized are $3 / 43=0.07$, $1 / 5=0.2$, and $16 / 27=0.59$ in the fields of technology, management, and strategy systems respectively. Almost of the subjects in target department includes contents of technology field. The recognition degree before the class for technical terms of technology system field was comparatively high. Therefore significant difference was recognized for little terms in the field. As few contents of strategy system field were taught, it is suggested that significant difference was recognized for many terms in the field.

Correct rates of the morning problems of the Fundamental Information Technology Engineer Examination $(\mathrm{FE})$ in the class and final exam were $30.3 \%$ and $82.0 \%$ for 49 common problems among 80 problems respectively. Correct rate in the final exam was more than $60 \%$. The result of the t-test between their rates shows significant difference $(\mathrm{t}(48)=23.8, \mathrm{p}<.001)$. It is suggested that this lecture achieved one of the purposes of this lecture which enable the students to answer $60 \%$ or more of the morning problems of the FE.

Another purpose of the class was "to deepen their knowledge of information technology." Various activities were used in the class for this purpose. "(31) knowledge of technology systems, (32) knowledge of management systems, and (33) knowledge of strategy systems" had all significantly improved. This then led to the supposition that knowledge had been deepened as knowledge related to FE as well as most of the attitude items related to the FE significantly improved. 
Because the overall attitude related to abilities had improved as explained in section 3.2, it is suggested that another purpose of the lecture to improve their ability to solve various problems was brought to realization through a lot of activities. As shown in Table 2, the evaluation item of "(26) Problemsolving ability" improved significantly through the various activities that took place in the class.

As shown in Table 4, the cluster of activity related to a clicker is " 1 . Activities related to rewriting reports and answering with clickers." No. of activities that were enumerated in this cluster is 412 . As activities that use a clicker among them, No. of frequencies that " 12 . Replying answer using clickers" is enumerated is 45 . This activity is enumerated by one or two persons for all of 34 attitudes. It is suggested that this activity is useful to improve many attitudes. Meanwhile, "13. Watching the distribution counted by clickers" is enumerated by only 8 and for seven attitudes. It is revealed that this activity is useful for only restrictive attitude.

As shown in Table 5, the finding that all of 30 activities were helpful in improving any attitude of the 34 items was obtained from the cross-tabulation of attitudes and activities. It is suggested that a series of activities, such as taking a class, answering about problems in morning, writing a report about it, answering to a quiz and studying for final exam, fostered thinking ability and problem-solving ability in this lecture.

\section{Conclusion}

Classes involving exercises on the subject of information were held at a university using clickers and surveys on the degree of the student's recognition of the terms and attitude of abilities were conducted. The survey data was analyzed using significance tests. The activities that helped improve attitude were investigated, a cross tabulation table on attitude and activities subjected to cluster analysis, and $\mathrm{x}^{2}$ tests conducted for the cross table tabulated into attitude and activity clusters.

The following effects were confirmed in (1) to (4). Having become clear from the results of cluster analysis and $\mathrm{x}^{2}$ test is shown in (5). Having achieved all of three purposes in this class is explained in (6):

(1) Overall degree of term recognition was improved, and the overall amount of knowledge increased.

(2) The degree of recognition improved by about $1 / 4$ with regard to the terms, in addition to improved knowledge.

(3) Overall rating value of attitude related to abilities improved.

(4) Attitude improved and increased in relation to most abilities.

(5) "Activities related to rewriting reports and answering with clickers" help improve "attitude related to expression, evaluation and correction."
"Activities related to report preparation and learning through e-learning" tend to improve "attitude related to expression, evaluation and correction." "Activities that involve questioning friends" help improve "attitude related to cooperation, questioning and communication" and "attitude related to expression, evaluation and correction." "Activities that involve listening to explanations, preparation, review, and study" help improve "attitude related to thinking, and the pursuit, implementation and deepening of knowledge and understanding." "Activities that involve listening to lectures" help improve "knowledge of FE and understanding of computers." (6) All of three following purposes in this class were achieved through the various activities that took place in the lecture: "to deepen understanding of knowledge from information technology;" "to enable the students to answer $60 \%$ or more of the morning problems of the Fundamental Information Technology Engineer Examination;" and "to improve the ability to solve various problems that will be required in actual society."

In the future the author would like to devise the even more creative classes by considering how clickers can be used to further improve the effect and then measure the learning effect of implementation of the classes.

\section{Acknowledgements}

The author appreciate the support of the Grant-inAid for Scientific Research, foundation study (C 25350364) given by the Ministry of Education, Culture, Sports, Science, and Technology, of Japan for this research.

\section{References}

[1] Adachi, K., "Analysis of the classification of the learners' activities in blended learning", Japan Journal of Educational Technology, 31 (1), 2007, pp.29-40.

[2] Bersin, J., The blended learning book: best practices, proven methodologies, and lessons learned. John Wiley \& Sons, Inc., San Francisco, USA, 2004.

[3] Central Council for Education or Construction of College Program Education (Report), http://www.meti.go.jp/press/20080627007/200806270073.pdf, 2008 (Access date: 5 December, 2012).

[4] Information-technology Promotion Agency, Japan Fundamental Information Technology Engineer Examination, http://www.jitec.ipa.go.jp/1_08gaiyou/ _index_gaiyou.html, 2012 (Access date: 5 December, 2012).

[5] Kimura Information Technology, "User's Guide for 3eAnalyzer, Office2007 Ver.4.5.4.1,” 2011. 
[6] Miyaji, I. and Yoshida, K., "The Practice and learning effect of education by blending of lecture and e-learning", Transactions of Japanese Society for Information and Systems in Education, 22 (4), 2005, pp.230-239.

[7] Miyaji, I., Yoshida, K., and Naruse, Y., "The effects of blending e-learning and lectures utilizing a structured notebook", Transactions of Japanese Society for Information and Systems in Education, 24 (3), 2007, pp.208-215.

[8] Miyaji, I. (Ed.), Toward Blended Learning from Elearning, Kyoritu-Shuppan, Tokyo, Japan, 2009.

[9] Miyaji, I., Comparison between Effects in Two Blended Classes Which E-learning is Used inside and outside Classroom, US-China Education Review, 8(4), 2011, pp.468-481.

[10] Mochizuki, T., Nakahara, A., Yamanouchi, Y., et al., "Analysis of student evaluation of e-learning programs cooperated with campus classrooms", Transactions of Japanese Society for Information and Systems in Education, 20 (2), 2003, pp.132-142.

[11] Nakashima, T., "Supporting for teaching improvement by integrating video recording with real-time feedback through response analyzers", Japan Journal of Educational Technology, 32 (2), 2008, pp.169-179.

[12] Nishimori, T., Nakahara, A., Mochizuki, T., et al., "Development of the e-learning system cooperating with lessons in classrooms of higher education", Japan Journal of Educational Technology, 27 (Suppl.), 2003, pp.9-12.

[13] Non-profit organization Japan E-learning Consortium (Ed.), E-learning White Paper 2008/2009 editions, Tokyo Denki University Press, Tokyo, Japan, 2008, pp.58-83.

[14] Sakai, K., "Development of interactive lesson by use of power feedback NOTE synchronizing clicker with video", Research Report of Japan Society for Educational Technology, JSET09-5, 2009, pp.87-94.

[15] Suemoto, T., Kamada, Y., Segawa, S., and Matsumoto, T., "Motivation for learning ICT skills by polling with clickers and group works at SNS", Japanese Society for Information and Systems in Education Research Report, 3 (5), 2009, pp.92-99.

[16] Suzuki, H., Takesada, M., Hikihara T., Yamada K., Hosokawa, T., and Onodera A., "Active learning in the classroom using the response system clicker: Report of a Physics class in Hokkaido University in 2007," Journal of Higher Education and Lifelong Learning Hokkaido University, No.16, 2008, pp.1-17. 